GRASAS Y ACEITES 71 (2)

April-June 2020, e357

ISSN-L: 0017-3495

https://doi.org/10.3989/gya.1171182

\title{
Camellia oil saponins: Solid phase extraction and its effect on mice blood and organs
}

\author{
H.O.A. Ahmed ${ }^{\mathrm{a}}$, C.M. Wang ${ }^{\mathrm{a}, \bigotimes}$, A.A. Mariod ${ }^{\mathrm{b}, \mathrm{c}, \bigotimes}$ and T.A.A. Hammoda $^{\mathrm{d}}$ \\ ${ }^{\mathrm{a}}$ Department of Food Science and Engineering, Institute of Food Science and Technology, \\ Huazhong Agricultural University, Wuhan 430070, China.
${ }^{b}$ Department of Biology, College of Science and Arts, University of Jeddah, Alkamil, KSA. \\ Indigenous Knowledge and Heritage Center, Ghibaish College of Science and Technology, Ghibaish, Sudan. \\ ${ }^{\mathrm{d}}$ College of Engineering and Technical Studies, Elimam Elmahadi University, Kosti, Sudan. \\ ${ }^{\square}$ Corresponding authors: cmwang@mail.hzau.edu.cn; basitmariod58@gmail.com
}

Submitted: 17 November 2018; Accepted: 14 May 2019; Published online: 1 July 2020

\begin{abstract}
SUMMARY: In this study, the tea saponin extracted experiment was adopted to optimize extraction conditions. The solid phase extraction technique was used to extract saponin from camellia tea oil. Four macro-porous resins (DM301; NKA-9; HZ-841; S-8), two cation exchange resins (D001; 732), chitosan and diatomite, respectively, were used in a preliminary experiment; the HZ-841 macro-porous resin was determined as the optimal solid adsorbent material. The extraction conditions were; temperature $23.78^{\circ} \mathrm{C}$; adsorption time 5.20 hour; liquid-to-solid ratio 12.54:1; predicted adsorption rate $20.20 \%$; ethanol concentration $83.27 \%$; eluent flow rate $1.18 \mathrm{~mL} / \mathrm{min}$; liquid-tosolid ratio 21.85:1; and the elution rate of tea saponin was calculated as $59.55 \%$. The effect of tea seed oil saponin on mice blood and organs (liver, kidney, spleen and heart) was studied. The mice were randomly divided into six groups and fed for 90-days. Their weights were recorded every day. On the last day of the experiment serum elements: Total cholesterol (TC), triglycerides (TG), low and high-density lipoproteins (LDL, HDL), as well as AST (aspartate aminotransferase), ALT (alanine aminotransferase) and total protein (TP) and organ (liver, kidney, spleen and heart) histopathologies were determined. The study results demonstrated that tea oil saponin expanded TC, TG, LDL and HDL. However, it generally increased ALT, AST activities and TP values compared to control groups. Tea oil saponin had no effect on organ tissue histopathology compared to control groups.
\end{abstract}

KEYWORDS: 90-days feeding; Camellia seed oil; Solid phase extraction; Tea saponin; Toxicity

RESUMEN: Saponinas de aceite de camelia: extracción en fase sólida y su efecto en sangre y órganos de ratones. En este estudio se optimizaron las condiciones de extracción de las saponina de té. La técnica de extracción en fase sólida se utilizó para extraer la saponina del aceite de té de camelia. Se utilizaron cuatro resinas macroporosas (DM301; NKA-9; HZ-841; S-8), dos resinas de intercambio catiónico (D001; 732), quitosán y diatomita, respectivamente, en un experimento preliminar. La resina macroporosa HZ-841 se determinó como el material adsorbente sólido óptimo. Las condiciones de extracción fueron: temperatura de $23,78{ }^{\circ} \mathrm{C}$, tiempo de adsorción de 5,20 horas, relación líquido:sólido: 12,54:1; tasa de adsorción prevista: 20,20\%; concentración de etanol: $83,27 \%$, el flujo de eluyente de $1,18 \mathrm{ml} / \mathrm{min}$, relación de líquido:sólido de $21,85: 1$, y la velocidad de elución de la saponina del té se calculó como 59,55\%. Se estudió el efecto de la saponina del aceite de semilla de té en la sangre y los órganos de los ratones (hígado, riñón, bazo y corazón). Los ratones se dividieron al azar en seis grupos y se alimentaron durante 90 días, y se registraron sus pesos todos los días. En el último día del experimento se detectaron histopatología en los elementos séricos: colesterol total (TC), triglicéridos (TG), lipoproteínas de baja y alta densidad (LDL, HDL), AST, ALT y proteína total (TP) y órganos (hígado, riñón, bazo y corazón). Los resultados del estudio demostraron que las saponinas del aceite de té aumentaron el TC, TG, LDL y HDL. Sin embargo, también en general aumentó las actividades de ALT, AST y los valores de TP en comparación con 
los grupos de control. Las saponinas del aceite de té no tuvieron efecto sobre la histopatología de tejidos de los órganos en comparación con los grupos de control.

PALABRAS CLAVE:; Aceite de semilla de camelia; Días de alimentación; Extracción en fase sólida; Saponina de té, Toxicidad.

ORCID ID: Ahmed HOA https://orcid.org/0000-0002-9979-0844, Wang CM https://orcid.org/0000-0002-24503388, Mariod AA https://orcid.org/0000-0003-3237-7948, Hammoda TAA https://orcid.org/0000-0001-9227-7880

Citation/Cómo citar este artículo: Ahmed HOA, Wang CM, Mariod AA, Hammoda TAA. 2020. Camellia oil saponins: Solid phase extraction and its effect on mice blood and organs. Grasas Aceites 71 (2), e357. https://doi.org/10.3989/ gya.1171182

Copyright: (C2020 CSIC. This is an open-access article distributed under the terms of the Creative Commons Attribution 4.0 International (CC BY 4.0) License.

\section{INTRODUCTION}

Camellia oil from Camellia oleifera, is a natural, edible oil in China and is considered a very old edible vegetable oil in southern China. It contains highly unsaturated fatty acids, polyphenols, vitamin $\mathrm{E}$ and carotene. The FAO recommended camellia oil as a healthcare plant oil (Pu, 1995; Wu et al., 2005), with similar properties as olive oil, which can be used as cooking oil (Hu and Yang 2018). Tea saponin was frequently disposed of with the oil cake or used as manure in the conventional oil preparing techniques. Tea saponin is viewed as a solid frothing, emulsifying, scattering and wetting agent, with various therapeutic uses. It has been utilized extensively in various field (Wu et al., 2018), food, chemical, industrial, agricultural and construction applications as well as in numerous fields of materials, metallurgy and metal processing (Qiu et al., 2011; Tang et al., 2008). Generally, saponins are amphipathicglycosides assembled phenomenologically by the soap-like foam they produce when shaken in aqueous solutions, and basically by having at least one hydrophilic glycoside moiety joined with a lipophilic triterpene or steroid derivative (Hostettmann and Marston 1995). It contains highly bioactive components. Previous research showed that tea saponin's foaming ability is better than fine soap (Leaves, 2002; Xu and Yan, 2011). The structure of tea saponin is shown in Figure 1, and its relative molecular weight is 1222.54 (Yuan et al., 2007).

Over $80 \%$ of analysis time is spent on sample accumulation and sample arrangement, so sample preparation is a major part of the analysis procedure. Customarily, liquid-liquid extraction has been used to screen for general questions. In any case, solid-phase extraction (SPE) has become a prominent option, because of its straightforwardness and economy as far as time and solvent concentration (Płotka-Wasylka et al., 2015) are concerned. Recently there has been sustainable advancement in extraction innovation with the improvement of new and less difficult example arrangement techniques, for example, supercritical fluid, which has been generally applied to separating bioactive mixes, for example, saponins (Wu et al., 2018).

Traditional and modern processing methods have been used for the extraction of tea saponin from tea seed meal as raw material, e.g. hot press extraction, organic solvent extraction and supercritical fluid extraction (Liu, 2007). There are disadvantages to each one of those preparing strategies: conventional hot-press extraction results in lower than desirable yields; solvent extraction is related to ecological concerns; and supercritical fluid extraction requires high pressures and is costly, thus limiting its application (Shen et al., 2010). Food toxicology has been divided into toxicity; grave toxicity; sub grave toxicity and chronic toxicity tests for in vivo and in vitro toxicity experiments (Xu and Yan, 2011; Wu et al., 2005).

Macroporous resin is an organic adsorbent composed of high molecular weight polymers. It has an internal three-dimensional stereoscopic pore structure and good adsorption properties due to the numerous reticular cavities with large specific surface areas. Macroporous resin can be used for purifying chemical substances from plant materials according to the polarity, relative molecular weight and different solubility of the objects (Liu et al., 2016a).

Saponins extracted from green tea leaves showed antihypercholesterolemic activity in mice by restraining cholesterol absorption in the digestive tracts, and it essentially brought down cholesterol and triglyceride levels in the liver (Matsu et al., 2009). An in vivo test giving tea saponin $(5.0 \mathrm{~g} / \mathrm{kg} \mathrm{BW})$ to mice demonstrated no poisonous quality in the liver, kidney, heart, thymus, or spleen of the treated mice and none of the mice died throughout the 15 days of the examination (Du et al., 2016). The present study focuses on the extraction of tea saponin from camellia oil by the solid-phase extraction technique as a simple and convenient new method. The study also focuses on the effect of extracted saponin on mice blood and organs.

\section{MATERIALS AND METHODS}

The following experimental material were used: $96 \%$ of tea saponin (Shanghai Violet Reagent Factory); camellia oil (Jiangxi Yuansen Polytron 


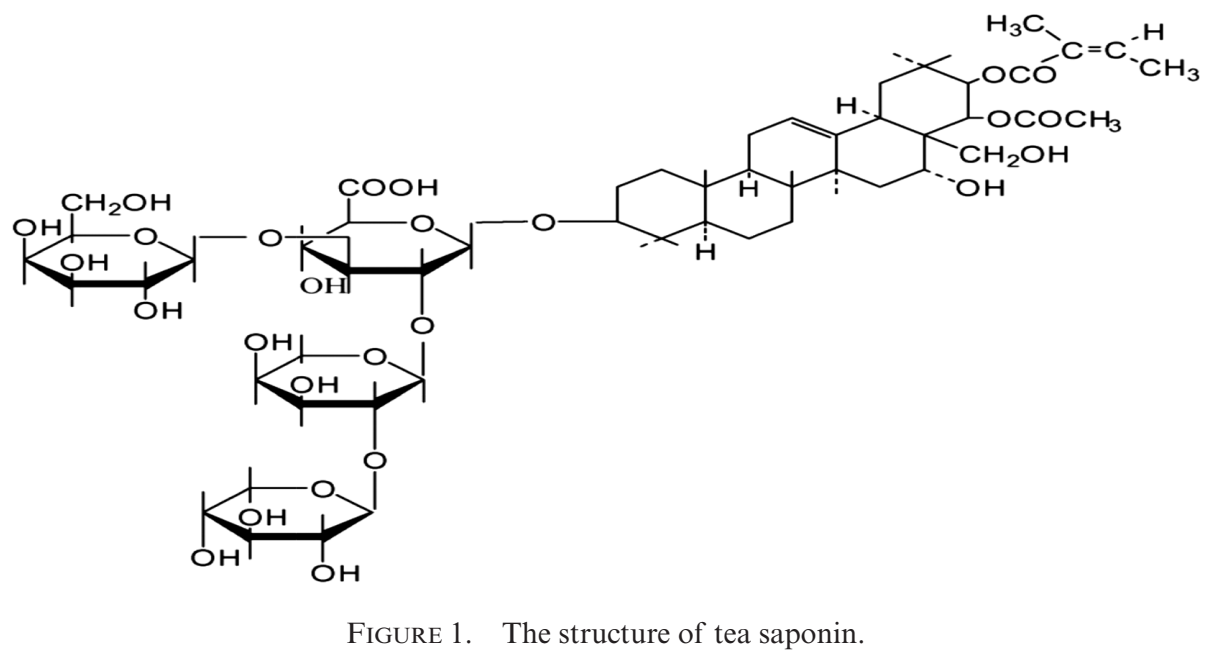

Technologies Inc); concentrated sulfuric acid AR (Xinyang Chemical Reagent Factory); sodium hydroxide AR (National Pharmaceutical Group Chemical Reagent Co., Ltd.); ethanol AR (National Pharmaceutical Group Chemical Reagent Co., Ltd.); vanillin AR (Sinopharm Chemical Reagent Co., Ltd.); concentrated hydrochloric acid AR (National Pharmaceutical Group Chemical Reagent Co., Ltd.); macroporous resin DM301, macroporous resin NKA-9, macroporous resin HZ-841, macroporous resin S-8 (Shanghai Speed Science Equipment Co., Ltd.); D001 type cation-exchange resin (Anhui Samsung Resin Technology Co., Ltd.); 732-type cation exchange resin, chitosan $\mathrm{BR}$, diatomite $\mathrm{AR}$, acetone (Chinese Medicine Group Chemical Reagent Co., Ltd.); qiagen integral protein, albumin kit, alanine aminotransferase (ALT) kits, aspartate aminotransferase (AST) kit triglyceride kits, and total cholesterol kits (Technology Co., LTD).

\subsection{Extraction of tea saponin from camellia tea oil}

\subsubsection{Pre-treatment of macro-porous and cation exchange resins}

A proper amount of macro-porous resin $(1.2 \mathrm{~g})$ was taken into a beaker; $50 \mathrm{ml}$ of $95 \%$ ethanol was added for $12 \mathrm{hrs}$, and then washed. Washing was repeated 3 times. After washing $30 \mathrm{ml}$ of a $3 \% \mathrm{HCl}$ solution was used; the solution was soaked for $5 \mathrm{hrs}$, washed to neutral $\mathrm{pH}$, and then soaked in a $0.5 \mathrm{~mol} / \mathrm{L} \mathrm{NaOH}$ solution for 5 hours, and washed with distilled water to neutral pH (Liu et al., 2013).

\subsubsection{Screening method of solid adsorption material}

$1.2 \mathrm{~g}$ of eight solid materials were taken into a conical flask, $15 \mathrm{~mL}$ of camellia oil were added to a gas bath at $25^{\circ} \mathrm{C}$, at $200 \mathrm{r} / \mathrm{min}$, and $6 \mathrm{~mL}$ of the supernatant oil samples were shocked in a round flask for $5 \mathrm{hrs}$. After adding $30 \mathrm{~mL}$ of ethanol solution (1 $\mathrm{mol} / \mathrm{L} \mathrm{NaOH}$ ) in a boiling-water bath, it was returned to liquid after $1 \mathrm{hr}$, and then the ethanol was removed by vacuum distillation at about $100 \mathrm{~mL}$ at $40{ }^{\circ} \mathrm{C}$. The resulting liquid obtained from the $5 \mathrm{~mL}$ was diluted 20 times. The absorbance of $0.5 \mathrm{~mL}$ diluted solution was measured and the value was reported. The content of tea saponin in camellia oil was calculated according to the following formula:

Adsorption capacity $\mathrm{Q}(\mathrm{mg} / \mathrm{mL})$

$$
=\frac{\left(\frac{\mathrm{A}+0.0544}{1.63}\right) \times 4000}{6}
$$

Adsorption rate $\mathrm{R}(\%)$

$$
=\left(\frac{\text { QTea oil }- \text { Qmatrial science }}{\text { QTea oil }}\right) \times 100 \%
$$

Where:

Q: the adsorption amount in $\mathrm{mg} / \mathrm{mL}$; A: $550 \mathrm{~nm}$ under the conditions of the absorbance value of the liquid soap; R: the adsorption Rate \% (Liu et al., 2013).

\subsubsection{Single factor experiment of adsorption temperature and time}

A quantity of 1.2 grams resin were pre-treated (wet weight, surface water was dried with filter paper) in a conical flask, then added to $15 \mathrm{~mL}$ of camellia oil under control conditions: shock speed $200 \mathrm{r} / \mathrm{min}$, shock adsorption $4 \mathrm{hrs}$, temperatures of $20{ }^{\circ} \mathrm{C}, 30^{\circ} \mathrm{C}, 40{ }^{\circ} \mathrm{C}, 50{ }^{\circ} \mathrm{C}, 60^{\circ} \mathrm{C}$, respectively. Then spectrum-photometry was used to determine the 
absorption value and the tea saponin adsorption rate was calculated (Liu et al., 2016a).

\subsubsection{Liquid:solid ratio single-factor experiment}

The camellia oil and resin after pre-treatment, in liquid-solid ratios (mL:g) of 9:1, 10:1, 11:1, 12:1, 13:1 were subjected to shock conditions: speed 200 $\mathrm{r} / \mathrm{min}$, temperature $25^{\circ} \mathrm{C}$, time 5 hours. Under these conditions and after the shock absorption, a spectrophotometer was used to measure the absorbance value, and then tea saponin adsorption rate was calculated (Liu et al., 2013).

\subsubsection{Single-factor experiment on concentration of elution solution}

In optimal conditions of adsorption, the adsorption resin stays in the upper oil phase. As tea saponin is insoluble in acetone, camellia oil was dissolved in acetone. The acetone was washed with the attached oil resin, then filtered. After the resin was packed, $20 \%, 50 \%, 70 \%$ and $90 \%$ ethanol solutions were used. The flow rate of $1 \mathrm{~mL} / \mathrm{min}$ was controlled and the liquid-to-solid ratio 25:1 was eluted. The spectrophotometric method was used to determine the eluent absorption value; and the elution rate of tea saponin was calculated. The elution rate of tea saponin was calculated according to the following formula:

elution rate $\mathrm{R}(\%)=\frac{\left(\mathrm{W}_{1} / \mathrm{m}_{1}\right)}{\left(\mathrm{W}_{2} / \mathrm{m}_{2}\right)} \times 100 \%$

$\mathrm{W}_{1}$ : tea saponin content, eluted from the resin of $\mathrm{mg} ; \mathrm{m}_{1}$ : elution resin dosage $(\mathrm{g}) . \mathrm{W}_{2}$ : Tea saponin content, resin adsorption $\mathrm{mg} ; \mathrm{m}_{2}$ : adsorption resin (g) (Liu et al., 2013).

\subsubsection{Single-factor experiment of elution flow rate}

A $90 \%$ ethanol solution was used to incorporate the resin at a controlled flow rate of $1 \mathrm{~mL} / \mathrm{min}$, $1.5 \mathrm{~mL} / \mathrm{min}, 2 \mathrm{~mL} / \mathrm{min}$ and $3 \mathrm{~mL} / \mathrm{min}$, at a liquidto-solid ratio elution of 20:1. After applying the spectrophotometric method for the determination of the eluent absorption value of $\mathrm{A}$, the elution rate of tea saponin was calculated (Liu et al., 2013).

\subsubsection{Use of Design-Expert ${ }^{\circledR}$ software for response surface methodology (RSM)}

Design-Expert software and response surface methodology were used to explain the interaction between the factors of response surface analysis and response surface curve. The correlation between independent and dependent factors was graphically supported by $3 \mathrm{D}$ reaction surface and $2 \mathrm{D}$ form plots produced by a prototype. The software generated the optimum saponin adsorption rate to reveal the conditions which gave the most extreme results (Shen and $\mathrm{Wu}, 2017$ ).

\subsection{Determination of the effect of tea saponin}

\subsubsection{Experimental design}

60 healthy male Kunming mice, five weeks old, 25 to $30 \mathrm{~g}$ weight, SPF (specific pathogen free), purchased from the Center for Disease Control (CDC), Hubei province, China were used. The animal number was No. 42000600002931. Mice feed was provided by the experimental animal research center of Hubei province and the qualified number was 42000500000068. The mice were fed with tea oil containing tea saponin for 90 days; they were housed in a room with temperature $\left(18\right.$ to $\left.24^{\circ} \mathrm{C}\right)$, and relative humidity $(40 \%$ to $60 \%)$. All the experiments were performed at the College of Food Science and Technology; Huazhong University; Hubei Provence; Wuhan; China. The mice were separated into various cages, each with 10 mice. They were stamped, weighed, and fed with essential feed, with versatile feeding and monitored for seven days. The mice were then arbitrarily partitioned into six groups of 10 mice each, all male sex. A normal group (control A), rapeseed oil group (control B) were taken as control groups. Tea saponin/water (C), low (D), medium (E) and high (F)-dose groups were also assigned. All systems were led as per the standards and methodology illustrated in the National Institutes of Health Guide on the Care and Use of Laboratory Animals (NIH, 1997). All the experiments were approved and reviewed by the Institutional Animal Welfare and Research, Ethics Committee guidelines of Huazhong Agricultural University, Wuhan, China (Approval number: 31273519).

\subsubsection{Dose regime}

All mice had free food and water intake; they were given an intra-gastric administration every morning from 8:00-9:00 once a day. The normal group (control A) was given standard saline; and control B was given rapeseed oil $(0.01 \mathrm{~mL})$. The other groups were given the comparing test substance (tea oil containing tea saponin) at $28,255,382.5$, and $510 \mathrm{mg} /$ $\mathrm{kg}$. bw. The mice were weighed every week and the activities of the mice, feeding, presence of poisoning and death, were observed every day. Drug dose was balanced by body weight.

\subsubsection{Experimental procedure}

The method of Abliz et al., (2014) was followed with some modifications. The mice were treated for 90 days, and fasted one day before the end of the 
trial. On the last day, they were weighed. They were fixed, and blood was gathered from their eyes. All the blood was left at room temperature for $0.5 \mathrm{hr}$, and was then centrifuged at $3000 \mathrm{rpm}$ for $10 \mathrm{~min}$. Serum was pipetted for the estimation of serum lipid concentration and the serum blood was determined using the automatic blood cell analyzer. After blood gathering, the heart, liver, spleen, and kidney were immediately taken and washed with super-cold saline; blotted on filter paper and weighed. The organ indexes were calculated by the following formula:

Organ index $\%=\left(\frac{\operatorname{organ} \text { weight }(\mathrm{g})}{\text { animal weight }(\mathrm{g})}\right) * 100$

The organs were washed and dried, and three examples were taken from each one. They were immediately put into glass vials loaded with $4 \%$ formaldehyde, and cooled to $4{ }^{\circ} \mathrm{C}$ the for histopathological examination (Abliz et al., 2014). Serum was used in the biochemical assays. Triglyceride (TG), total cholesterol (TC), high density lipoprotein (HDL), and low density lipoprotein (LDL) were determined using the TG kit, TC kit, HDL kit and LDL kit (Beijing wantai DRD CO., LTD., Beijing, PR China) (Shen, and Wu, 2017).

\subsection{Statistical analysis}

The analysis of variance (ANOVA) and RSM were used to compare the means or averages. All the analyses were carried out using IBM ${ }^{\circledR}$ SPSS $®$ Statistics V25 statistical software to compare treatment groups, $\mathrm{P}<0.05$ was considered statistically significant.

\section{RESULTS AND DISSCUTIONS}

\subsection{Screening of the best solid adsorption material}

In this study, the most suitable macroporous resin type for the isolation of tea saponins was determined, and provided technical support for the in-depth study of saponins (Liu et al., 2016a). Table 1 shows the adsorption properties of 8 kinds of materials (four macro-porous resins (DM301, NKA-9, HZ-841, S-8), two cation exchange resins (D001; 732), chitosan and diatomite) to determine the adsorption of tea saponin from camellia oil. Macroporous resin HZ-841 has the highest adsorption rate $(18.26 \%)$ and the best absorption capacity followed by macroporous resin S-8 and diatomite 16.3 and $16.4 \%$, respectively. Macroporous resin DM301 showed the lowest rate of adsorption $(6.79 \%)$, possibly due to its small size, which causes poor ability to absorb tea saponin from camellia oil. According to the results for HZ-841, macroporous resin can be selected as the best material for the solid
TABLE 1. Adsorption rates of $18.26 \%$ and $16.3-16.4 \%$ are significantly different*

\begin{tabular}{lc}
\hline Adsorption material & Adsorption rate \% \\
\hline Resin DM301 & $6.79 \pm 0.10^{\mathrm{g}}$ \\
Resin S-8 & $16.31 \pm 0.10^{\mathrm{bc}}$ \\
Resin HZ-841 & $18.26 \pm 0.20^{\mathrm{a}}$ \\
Resin NKA-9 & $11.29 \pm 0.20^{\mathrm{e}}$ \\
Cation D001 & $10.46 \pm 0.10^{\mathrm{f}}$ \\
Cation 732 & $10.60 \pm 0.20^{\mathrm{f}}$ \\
Chitosan & $12.82 \pm 0.10^{\mathrm{d}}$ \\
Diatomite & $16.45 \pm 0.10^{\mathrm{b}}$ \\
\hline
\end{tabular}

* Values reported are mean $\pm \mathrm{SD}(\mathrm{n}=3)$, the mean test was done using the least significant difference (LSD) test at confidence level $95 \%$. Means followed by different small letters within the column for each parameter are significantly different $(P \leq 0.05)$. Means followed by the same small letters within the column for each parameter are not significantly different $(\mathrm{P} \leq 0.05)$.

adsorption extraction of tea saponin from camellia oil. Macroporous resins have been widely used for the isolation and purification of saponins, alkaloids, flavonoids, peptides, carbohydrates and other chemicals. Liu et al., (2016a) reported that from 16 types of macroporous resin, D-101 and AB-8 were the two most commonly used for the extraction of saponins from tomato.

\subsection{Single-factor experiment of adsorption temperature}

The adsorption temperature is one of the main factors affecting the adsorption rate of tea saponin from camellia oil. According to the method used, the selected adsorption temperatures were $20^{\circ} \mathrm{C}, 30^{\circ} \mathrm{C}, 40^{\circ} \mathrm{C}, 50^{\circ} \mathrm{C}$ and $60^{\circ} \mathrm{C}$, respectively. Figure $2 \mathrm{~A}$ shows the effect of the adsorption temperature on the adsorption rate of tea saponin. The results showed that the tea saponin adsorption rate decreased with the increase in temperature, and the process of macroporous resin was exothermic. The temperature of $20^{\circ} \mathrm{C}$ was found to give highest tea saponin adsorption rate (17\%). Therefore, the adsorption should be read at a low temperature. Due to the increase in temperature during the summer, the conditions of $20^{\circ} \mathrm{C}$ cannot be guaranteed for isothermal adsorption, so the subsequent experimental temperature was set at $25^{\circ} \mathrm{C}$ for room temperature.

Figure 2B shows the effect of the adsorption time on the adsorption rate of tea saponin. According to the used method, the selected adsorption times were $2 \mathrm{hr}, 3 \mathrm{hr}, 4 \mathrm{hr}, 5 \mathrm{hr}$ and $6 \mathrm{hr}$, respectively. The results showed that the tea saponin adsorption rate was increased with the increase of time, where the maximum saponin adsorption rate of tea saponin from camellia oil was obtained at $5 \mathrm{hrs}$, then the adsorption rate remained stable, and the adsorption 

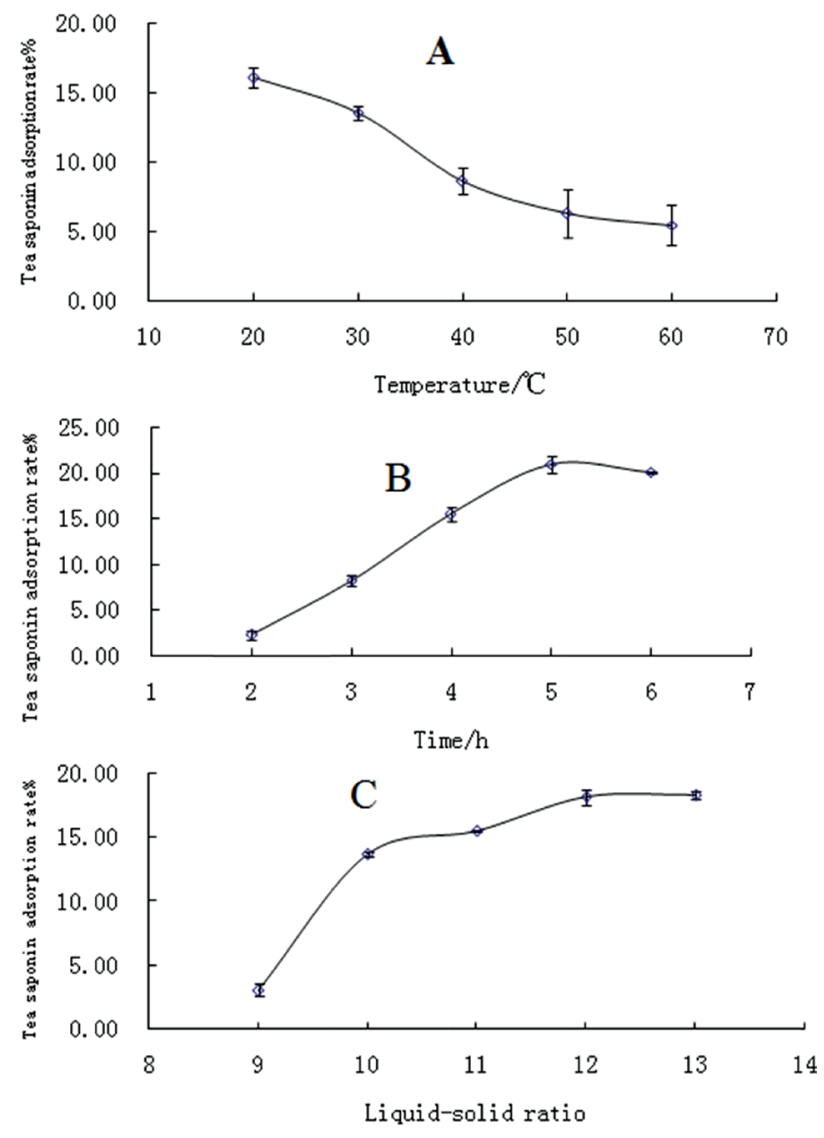

Figure 2. Effect of the adsorption temperature (A), time (B) liquid-to-solid ratio $(\mathbf{C})$ on the adsorption rate of tea saponin. The plotted data are the mean $\pm \mathrm{SD}$ values for experiments resulting from the mean of three replicates $(n=3)$.

equilibrium was reached during this suitable time for tea saponin extraction time.

Figure $2 \mathrm{C}$ shows the effect of the liquid-to-solid ratio of adsorption rate of tea saponin. The liquidto-solid ratios of 9:1, 10:1, 11:1, 12:1 and 13:1 (mL: g) were prepared. The results showed that the tea saponin adsorption rate increased with the increase in liquid-to-solid proportion. The liquid-to-solid ratio clarified that when the liquid-to-solid ratio expanded to a certain level, the lower the concentration of the solute, the greater the power of mass transfer. From an economic point of view, the increase in the ratio of liquid to solid is not significant. As seen in Figure 2C, when the liquid-solid ratio reached $12: 1$, the adsorption rate of tea saponin increased slowly, so 12:1 liquid-solid ratio was selected as the most appropriate for the extraction of tea saponin.

\subsection{Contour map and response surface methodology (RSM)}

In RSM, natural variables are transformed into coded variables that have been defined as dimensionless with mean zero and same standard deviation
(Liyana-Pathirana and Shahidi 2005). Initial investigations were conducted with the end goal of determining the effect of adsorption temperature and adsorption time on saponin adsorption rate (yield) of tea saponins. Figures $3 \mathrm{~A}-\mathrm{B}$, and 4 illustrate the interaction between the factors in response surface method and response surface curve. Distinctive states of the contor plots showed diverse relationships between the factors; a curved form plot demonstrated that the associations between the factors were significant while a circular contour plot implied something different (Liu et al., 2016b).

Figure $3 \mathrm{~A}$ shows the response surface plot and contour plot of the effect of adsorption temperature and adsorption time on tea saponin adsorption rate (yield). The increase in temperature from 20 to 23 improved the saponin yield. However, when the temperature was over $23^{\circ} \mathrm{C}$, there was a continuous decrease in the reaction, and extraction time after $5 \mathrm{hr}$ did not demonstrate any impact on saponin yield. It may have been that, by expanding the extraction time, the chemical degradation of bioactive compound in the extraction procedure may have occurred more rapidly, which brought about the lower extraction yield (Zhao et al., 2012).

Figure 3B shows the response surface and contour plots of the effect of adsorption temperature and the ratio of liquid-to-solid on tea saponin adsorption rate (yield). The increase in temperature from 20 to 24 improved the saponin adsorption rate, while the ratio of liquid-to-solid was 14.5:1. Figure 4 shows the response surface and contour plots of the effect of adsorption time and the ratio of liquid-to-solid on tea saponin adsorption rate (yield). The increase in time from 4.5 to 5.10 improved the saponin yield. However, when the time over 5.1, there was a gradual decline in the response, and extraction time after 5 hours did not show any obvious effect on saponin yield.

\subsection{Validation of model test}

The software showed that (Figure 2) the optimum saponin adsorption rate was $20.07 \%$; adsorption time was $5.2 \mathrm{~h}$; and the adsorption temperature was $23.78{ }^{\circ} \mathrm{C}$. Compared to the value predicted $(20.20 \%)$, the results showed that the actual value of $20.07 \%$ was very close to the actual results, and it shows that the response surface method is feasible.

\subsection{Single-factor experiment of the eluted liquid concentration}

Tea saponin is insoluble in pure ethanol, but easily soluble in a water and ethanol Mixture. Therefore, the mixture was chosen as the elution solution, as it is not toxic to humans and economically feasible. According to the method, the elution solution (ethanol) concentrations were 

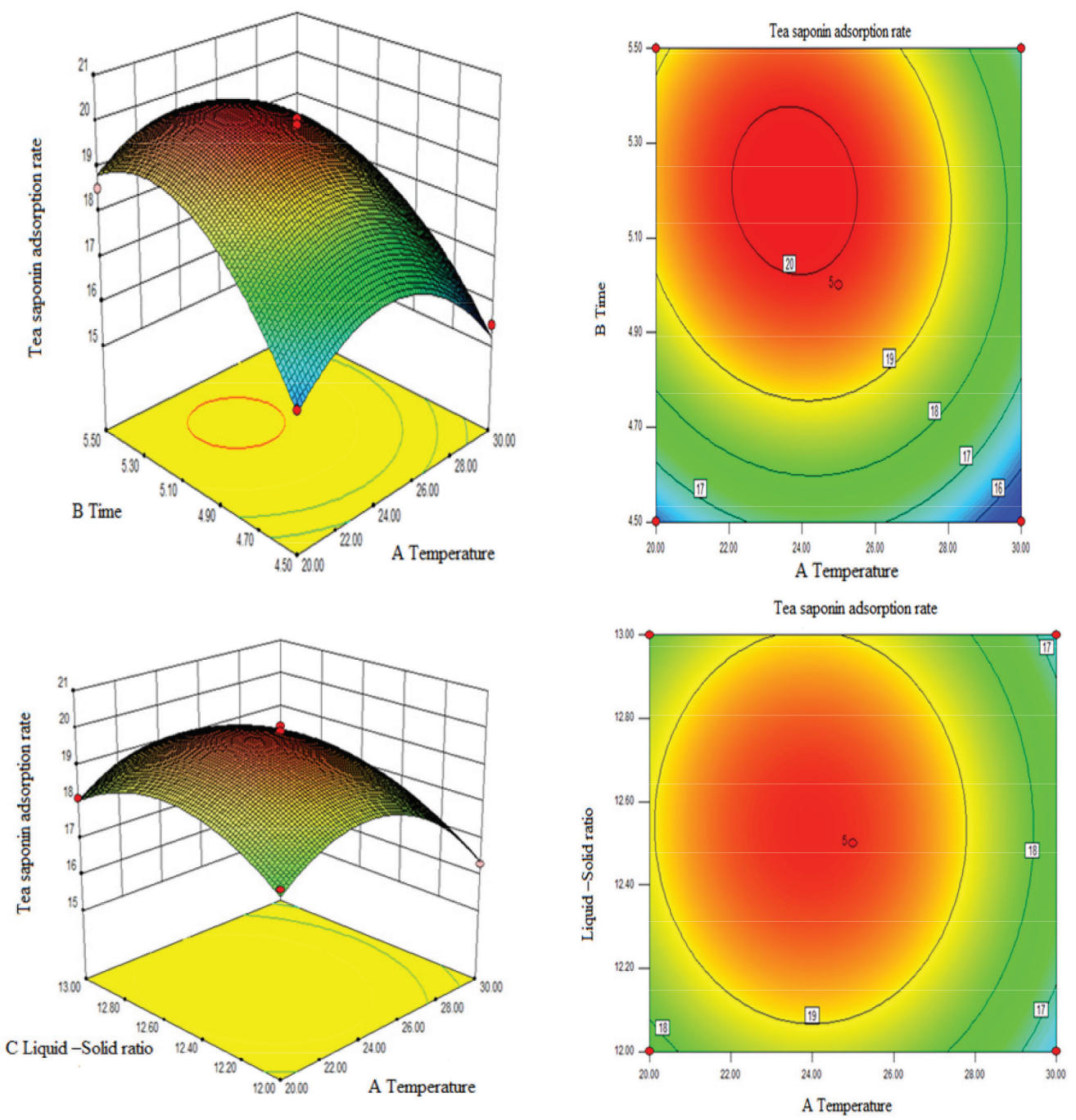

FIGURE 3. Response surface plot and contour plot of the effects of adsorption temperature and adsorption time (A) and the ratio of liquid-to-solid (B) on tea saponin adsorption rate (yield). The figures produced resulted from the mean of three replicates $(\mathrm{n}=3)$.
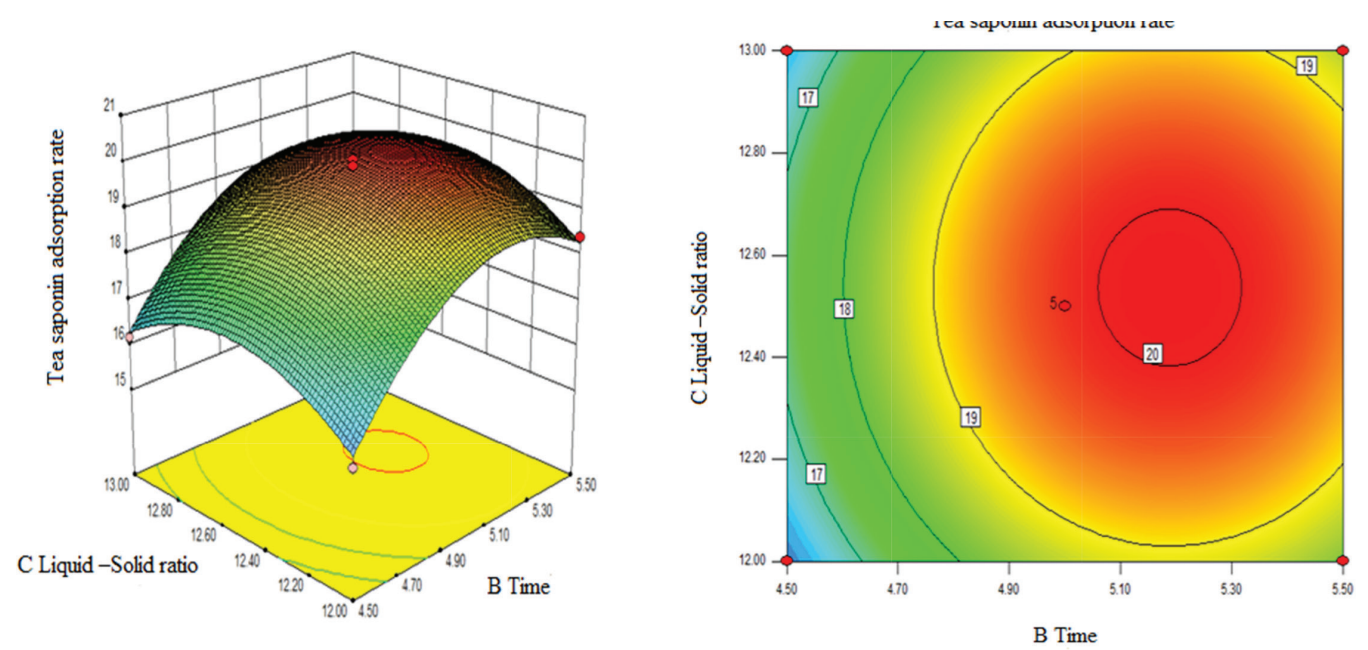

FIGURE 4. Response surface plot and contour plot of the effects of adsorption time and the ratio of liquid-to-solid on tea saponin adsorption rate (yield). The figures produced resulted from mean of three replicates $(n=3)$. 
$20,50,70$, and $90 \%$. With the increase in ethanol concentration, the tea saponin elution rate was increased (Figure 5. A.). When the ethanol concentration increased to about $80 \%$, the tea saponin elution rate showed only a slight change, so the best ethanol concentration was between 80 and $95 \%$. According to the experimental method used, four elution flow rates were selected, $1 \mathrm{~mL} / \mathrm{min}$, $1.5 \mathrm{~mL} / \mathrm{min}, 2 \mathrm{~mL} / \mathrm{min}$ and $3 \mathrm{~mL} / \mathrm{min}$, Figure $5 \mathrm{~B}$ illustrates how $1 \mathrm{~mL} / \mathrm{min}$ and $1.5 \mathrm{~mL} / \mathrm{min}$ are the highest flow rates for the elution rate of tea saponin. With the speeding up of the velocity, the resin attached to the surface of the tea saponin cannot be completely washed out. The flow rates of $1 \mathrm{~mL} / \mathrm{min}$ and $1.5 \mathrm{~mL} / \mathrm{min}$ were similar, so the flow rate of $1.5 \mathrm{~mL} / \mathrm{min}$ was chosen from the economic point of view.
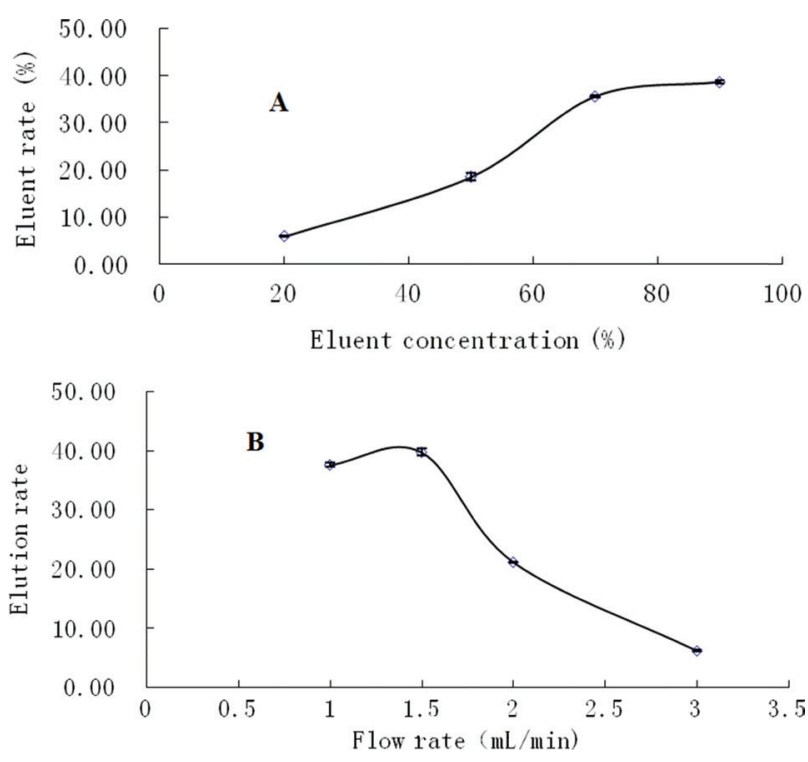

FIGURE 5. Effects of the eluent concentration (A), and the flow rate (B) on the elution rate of tea saponin. The figures produced resulted from the mean of three replicates $(n=3)$.

\subsection{The effect of camellia oil saponin on mice blood and organs}

\subsubsection{Serum lipids}

The effects of tea saponins of camellia oil on blood lipids in mice are shown in Table 2. In comparison with control group A, TC and TG were the important indexes which reflected the body lipid metabolism, and LDL was increased significantly in the model control group. HDL was increased in the model groups except for group F (high ratio of tea saponin/ oil). All the treatment groups had significantly higher TC, TG and LDL. All the measured parameters were dose-dependent and did not have a significant impact, which could explain the effect of the camellia oil with tea saponin on mice lipid metabolism.

\subsubsection{Effect of tea saponinon activities in ALT, AST and TP on the serum of mice}

Table 3A shows the effect of tea saponins from camellia oil on alanine aminotransferase (ALT), aspartate aminotransferase (AST), and total protein (TP) in the serum of mice for 90 days to assay toxicity. The doses of $28,255,382.5$ and $510 \mathrm{mg} / \mathrm{kg} /$ bw increased the ALT, AST, and TP levels in serum compared with the two control groups. The overall results suggested that AST, ALT and TP activities were increased, but as a general observation, the tea saponin did not show toxicity in mice serum.

\subsubsection{Effect of tea oil saponin on the body weight and organ index}

The body weights of the mice were recorded each day after tea oil saponin treatment. No changes in eating, drinking or exploratory behavior were seen in the mice treated with tea oil saponin. The body weight plot demonstrated that the weights of the mice expanded typically and no distinction was seen among the control and tea oil saponin-treated groups (data not shown). This suggested that the

TABLE 2. Effects of tea saponins from camellia oil on blood lipids in mice

\begin{tabular}{|c|c|c|c|c|c|}
\hline Group & Dosage $(\mathrm{mg} / \mathrm{kg} \cdot \mathrm{bw})$ & $\mathrm{TC}(\mathrm{mmol} / \mathrm{L})$ & TG (mmol/L) & LDL (mmol/L) & HDL (mmol/L) \\
\hline A & Control A & $2.17 \pm 0.04^{\mathrm{d}}$ & $1.21 \pm 0.04^{\mathrm{de}}$ & $0.07 \pm 0.02^{\mathrm{f}}$ & $1.09 \pm 0.06^{\mathrm{f}}$ \\
\hline B & Control B & $2.24 \pm 0.02^{\mathrm{c}}$ & $1.22 \pm 0.07^{\mathrm{d}}$ & $1.16 \pm 0.03^{\mathrm{d}}$ & $1.51 \pm 0.07^{\mathrm{cd}}$ \\
\hline $\mathrm{C}$ & (28) Tea saponin/water & $2.15 \pm 0.03^{\mathrm{d}}$ & $1.54 \pm 0.04^{\mathrm{c}}$ & $1.05 \pm 0.01^{\mathrm{e}}$ & $1.62 \pm 0.09^{\mathrm{a}}$ \\
\hline $\mathrm{D}$ & (255) Low tea saponin/oil & $2.16 \pm 0.02^{\mathrm{e}}$ & $1.57 \pm 0.01^{\mathrm{c}}$ & $1.63 \pm 0.09^{\mathrm{c}}$ & $1.59 \pm 0.04^{\mathrm{ab}}$ \\
\hline $\mathrm{E}$ & (382.5) Medill tea saponin/oil & $2.53 \pm 0.07^{\mathrm{b}}$ & $1.70 \pm 0.04^{\mathrm{b}}$ & $1.70 \pm 0.08^{\mathrm{b}}$ & $1.54 \pm 0.07^{\mathrm{bc}}$ \\
\hline $\mathrm{F}$ & (510) High tea saponin/oil & $2.81 \pm 0.04^{\mathrm{a}}$ & $1.83 \pm 0.04^{\mathrm{a}}$ & $1.82 \pm 0.04^{\mathrm{a}}$ & $1.46 \pm 0.01^{\mathrm{e}}$ \\
\hline
\end{tabular}

* Mean Value \pm Standard Deviation $(\mathrm{n}=3$ ), the mean test was done using ANOV-CRD- Dunnett t-test at confidence level $95 \%$. Means followed by different small letters within the column for each parameter are significant different $(\mathrm{P} \leq 0.05)$. Means followed by the same small letters within the column for each parameter are not significant different $(\mathrm{P} \leq 0.05)$. Where: TC: Total Cholesterol, TG: Total triglycerides, LDL: Low-Density Lipoprotein cholesterol, HDL: High-Density Lipoprotein cholesterol. 
TABLE 3A. Effects of tea saponins in camellia oil on ALT, AST and TP in serum of mice (A) and on organ index in mice (B)

\begin{tabular}{lllll}
\hline Group & Dosage (mg/kg·bw) & ALT(U/L) & AST(U/L) & TP(g/L) \\
\hline A & Control A & $43.03 \pm 0.03^{\mathrm{f}}$ & $153.50 \pm 0.70^{\mathrm{e}}$ & $56.03 \pm 0.014^{\mathrm{e}}$ \\
B & Control B & $59.87 \pm 0.04^{\mathrm{d}}$ & $155.90 \pm 0.80^{\mathrm{d}}$ & $62.07 \pm 0.02^{\mathrm{c}}$ \\
C & (28) Tea saponin/water & $59.09 \pm 0.05^{\mathrm{e}}$ & $153.25 \pm 0.40^{\text {ef }}$ & $69.06 \pm 0.03^{\mathrm{cd}}$ \\
D & (255) Low tea saponin/oil $^{\mathrm{c}}$ & $59.90 \pm 0.06^{\mathrm{c}}$ & $158.17 \pm 0.18^{\mathrm{bc}}$ & $69.17 \pm 0.07^{\mathrm{bc}}$ \\
E & (382.5) Medill tea saponin/oil $_{\text {F }}^{\mathrm{a}}$ & $60.02 \pm 0.02^{\mathrm{ab}}$ & $158.60 \pm 0.10^{\mathrm{ab}}$ & $69.19 \pm 0.01^{\mathrm{b}}$ \\
F & (510) High tea saponin/oil $^{\mathrm{b}}$ & $60.07 \pm 0.02^{\mathrm{a}}$ & $158.90 \pm 0.70^{\mathrm{a}}$ & $69.21 \pm 0.02^{\mathrm{a}}$ \\
\hline
\end{tabular}

* Mean Value \pm Standard Deviation ( $=3$ ), the mean test was done using ANOV-CRD- Dunnett t-test at confidence level $95 \%$. Means followed by different small letters within the column for each parameter are significantly different $(\mathrm{P} \leq 0.05)$. Means followed by the same small letters within the column for each parameter are not significantly different $(\mathrm{P} \leq 0.05)$. Where: ALT: Alanine aminotransferase, AST: Aspartate aminotransferase, TP: Total protein.

TABLE 3B. Effects of tea saponins in camellia oil on ALT, AST and TP in serum of mice (A) and on organ index in mice (B)

\begin{tabular}{|c|c|c|c|c|c|}
\hline Group & Dosage $(\mathrm{mg} / \mathrm{kg} \cdot \mathrm{bw})$ & Liver index \% & Kidney index $\%$ & Spleen index \% & Heart index \% \\
\hline A & Control A & $5.42 \pm 0.02^{\mathrm{a}}$ & $1.57 \pm 0.02^{\mathrm{de}}$ & $0.37 \pm 0.05^{\mathrm{b}}$ & $0.56 \pm 0.01^{\mathrm{a}}$ \\
\hline B & Control B & $5.19 \pm 0.01^{b}$ & $1.64 \pm 0.01^{\mathrm{a}}$ & $0.34 \pm 0.02^{c}$ & $0.48 \pm 0.02^{\mathrm{cd}}$ \\
\hline $\mathrm{C}$ & (28) Tea saponin/water & $4.91 \pm 0.04^{\mathrm{c}}$ & $1.45 \pm 0.04^{\mathrm{f}}$ & $0.39 \pm 0.02^{\mathrm{a}}$ & $0.32 \pm 0.01^{\mathrm{f}}$ \\
\hline $\mathrm{D}$ & (255) Low tea saponin/oil & $4.47 \pm 0.04^{\mathrm{d}}$ & $1.59 \pm 0.02^{\mathrm{cd}}$ & $0.31 \pm 0.05^{\mathrm{d}}$ & $0.46 \pm 0.01^{\mathrm{de}}$ \\
\hline $\mathrm{E}$ & (382.5) Medium tea saponin/oil & $4.44 \pm 0.06^{\mathrm{de}}$ & $1.61 \pm 0.01^{\mathrm{bc}}$ & $0.30 \pm 0.01^{\mathrm{dc}}$ & $0.50 \pm 0.02^{\mathrm{bc}}$ \\
\hline $\mathrm{F}$ & (510) High tea saponin/oil & $4.38 \pm 0.04^{\mathrm{f}}$ & $1.63 \pm 0.03^{\mathrm{ab}}$ & $0.29 \pm 0.01^{\mathrm{dce}}$ & $0.52 \pm 0.03^{\mathrm{b}}$ \\
\hline
\end{tabular}

* Mean Value \pm Standard Deviation ( $\mathrm{n}=3$ ), the mean test was done using ANOV-CRD- Dunnett t-test at confidence level 95\%. Means followed by different small letters within the column for each parameter are significantly different $(\mathrm{P} \leq 0.05)$. Means followed by the same small letters within the column for each parameter are not significantly different $(\mathrm{P} \leq 0.05)$.

tea oil saponin did not have a harmful impact to the body weight of the mice. Following 90 days of administrations, the mice were sacrificed and the significant organs were gathered. The organ indexes (organ weight/body weight) of the heart, liver, spleen, and kidney were ascertained and compared (Table 3B). The outcome demonstrated that the tea oil saponin had no undesirable impact on the organ indexes. Non significant differences were detected between the control and treated groups in kidney, spleen and heart, but significant differences were detected between the two control groups and groups $\mathrm{C}$ and $\mathrm{F}$ with regards to the liver. The livers were bigger in all groups compared to other organs.

\subsubsection{Mice organ histopathology}

The anatomy of mice organs (liver, kidney, spleen and heart) was observed by the naked-eye; and no differences were found between the control groups (A and B) and dose groups (C, D, E and F) concerning edema, hyperplasia, atrophy lesions, with brightcolor appearance, as the normal organs and without any hitopathological changes.

Figure 6a shows the heart histopathological tissue in Kunming mice. The heart tissue showed no changes in the control and dose groups and no abnormal accumulation or precipitation and no cavitations. Figure 6b shows kidney histopathological tissue in Kunming mice. The results for kidney tissues in the dose groups were roughly the same as the control groups with no significant differences, where there was clear renal tubular structure, complete epithelium, no crystals within the lumen, and no inflammatory cells. Figure $6 \mathrm{c}$ shows liver pathological tissue in Kunming mice. The figure shows ordinary liver tissue, with no changes in the appearance of the controls or the dose groups. There were big nucleus, neat veins closely surrounding cell tissues, and regular lobular, beside no cavitations, no abnormal accumulation or precipitation. Generally, the dose groups showed a normal liver tissue, fatty degeneration was not found in the liver either (Ghule et al., 2009), with no toxic effects. Figure 6d shows spleen histopathological tissue in Kunming mice. The figure shows tissue morphology; and all the groups were characterized by a clear organizational structure, some large volume and irregular polygonal cells, scattered distribution in the edge area of the spleen cells, red pulp spleen sonne and a lymph follicle germinal center can be clearly seen. All the treatment groups compared to the control groups were presented as normal, and there were no significant differences. Therefore, as the general results, camellia oil containing tea saponin did not 

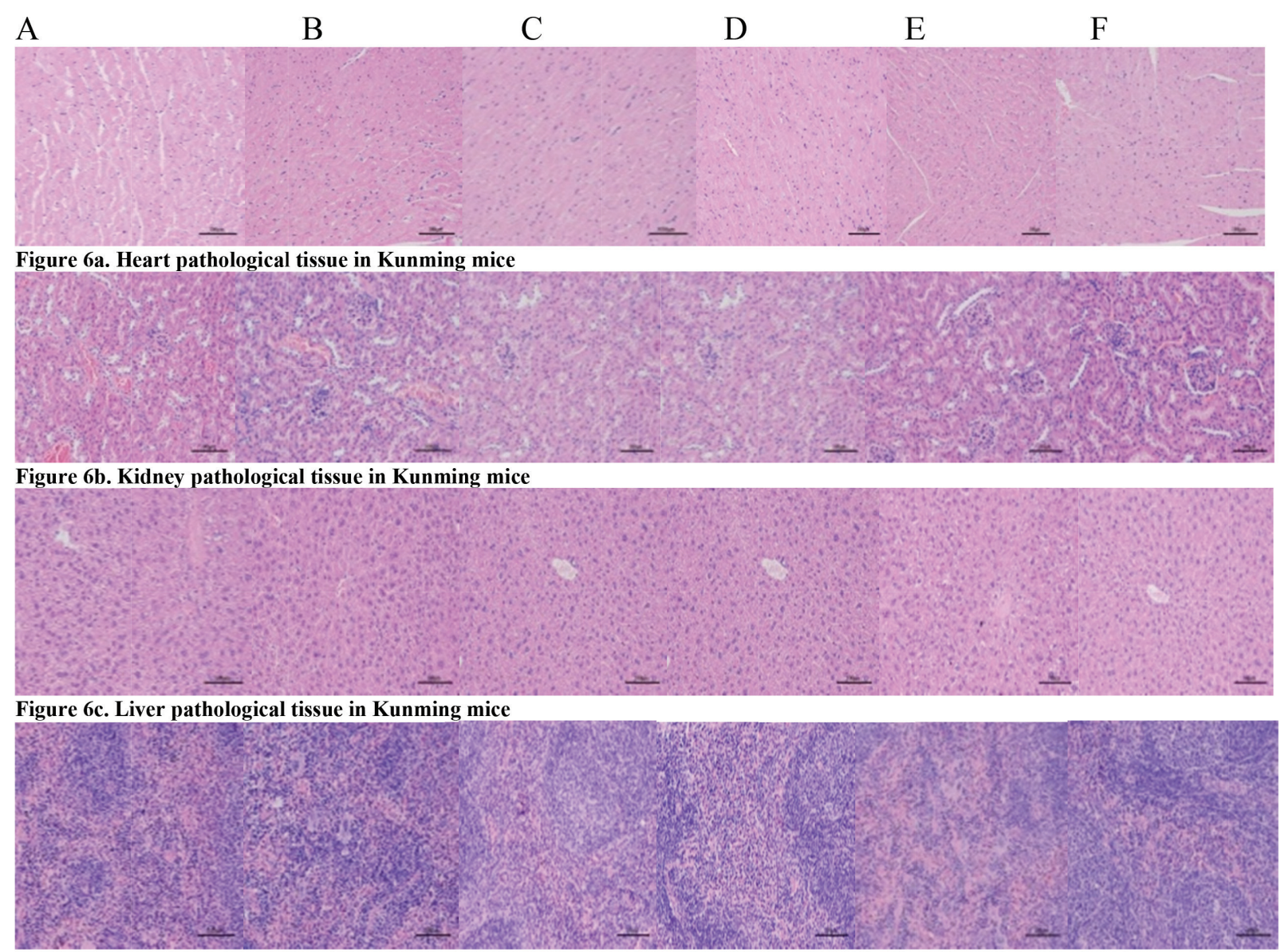

Figure 6d. Spleen pathological tissue in Kunming mice

WHERE:

Figure 6. A: Control A, B: Control B, C: Tea saponin/water, D: Low tea saponin/oil, E: Medium tea saponin/oil, F: High tea saponin/oil.

produce any adverse effects on mice heart, kidney, liver or spleen physiologies.

\section{CONCLUSIONS}

The adsorption temperature $23.78^{\circ} \mathrm{C}$, adsorption time $5.20 \mathrm{~h}$, liquid:solid ratio of $12.54: 1$ were considered the best conditions for camellia oil tea saponin adsorption. Under these conditions the adsorption rate of tea saponin was measured as $20.07 \%$, which was consistent with the predicted rate. The best elution of saponin from camellia oil was reported as $57.75 \%$, under the conditions of $83.27 \%$ ethanol concentration, $1.18 \mathrm{~mL} / \mathrm{min}$ flow rate, and 21.85:1 liquid-to-solid ratio. Our study confirmed no toxicity for tea saponin and that it was dose-dependent. The histopathological studies revealed that all treatment groups showed no significant differences compared to the control groups.

\section{ACKNOWLEDGMENT}

The first author thanks the Chinese Scholarship (CSC) for financial support.

\section{REFERENCES}

Abliz A, Aji Q, Abdusalam E, Sun X, Abdurahman A, Zhou W, Moore N, Umar A. 2014. Effect of Cydonia oblonga M ill. Leaf extract on serum lipids and liver function in a rat model of hyperlipidaemia. J. Ethnopharm. 151, 970-974. https://doi.org/10.1016/j.jep.2013.12.010

Chun Y, Jing Z. 2010. Effect of adsorption separation characteristics of macroporous resins for total flavonoids of chrysanthemum. J. Food Sci. 12, 127-131.

Du L, Fu QY, Xiang LP, Zheng XQ, Lu JL, Ye JH, Li QS, Polito CA, Liang YR. 2016. Tea polysaccharides and their bioactivities. Molecules 21, 1449; https://doi.org/10.3390/ molecules 21111449

Ghule BV, Ghante MH, Saoji AN, Yeole PG. 2009. Antihyperlipide mice effect of the methanolic extract from Lagenaria siceraria stand. Fruit in hyper lipidemic rats. $J$. Ethnopharmacol. 124, 333-337. https://doi.org/10.1016/j. jep.2009.04.040

Hostettmann K, Marston A. 1995. Saponins. Cambridge: Cambridge University Press. p. 3ff. ISBN 978-0-52132970-5. OCLC 29670810. https://doi.org/10.1017/CBO97 80511565113

Hu JB, Yang GL. 2018. Physiochemical characteristics, fatty acid profile and tocopherol composition of the oil from Camellia oleifera Abel cultivated in Henan, China. Grasas Aceites 69 (2), e255. https://doi.org/10.3989/ gya. 1224172

Leaves X. 2002. Tea saponin and exploitation. J. Chem. Prod. Technol. 9 (2), 6-8. 
Li N. 2007. The statue-sque and development of domestic food safety toxicology evaluation. J. Toxicol. 12, 368-370.

Liu K, Wang J, Gao W, Man S, Wang Y, Liu C. 2013. Preparative separation and purification of steroidal saponins in Paris polyphylla var. yunnanensis by macroporous adsorption resins. Pharm. Biol. 51 (7), 899-905. https://doi.org/10.31 09/13880209.2013.770537

Liu J, Yang Z, Lu F, Chen S, Li D. 2016a. Selection of Macroporous Resins for the Separation and Detection of Tomato Saponins. Proceedings of the 2016 6th International Conference on Advanced Design and Manufacturing Engineering (ICADME 2017). https://doi.org/10.2991/ icadme-16.2016.26

Liu Y, Li Z, Xu H, Han Y. 2016b. Extraction of Saponin from Camellia oleifera Abel Cake by a combination Method of Alkali Solution and Acid Isolation. $J$. Chem. 2016, Article ID 6903524, 8 pages. https://doi. org/10.1155/2016/6903524

Liu H. 2007. Tea saponin extraction and [D]. Analysis method Changsha: Hunan Agricultural University.

Liyana-Pathirana C, Shahidi F. 2005. Optimization of extraction of phenolic compounds from wheat using response surface methodology. Food Chem. 93, 47-56. https://doi. org/10.1016/j.foodchem.2004.08.050

Matsu Y, Kobayashi K, Masuda H. 2009. Quantitative Analysis of Saponins in a Tea-Leaf Extract and Their Antihypercholesterolemic Activity. Biosci. Biotechnol. Biochem. 73 (7), 1513-1519. https://doi.org/10.1271/ bbb. 90003

NIH. 1997. https://grants.nih.gov/grants/olaw/Guide-for-theCare-and-use-of-laboratory-animals.pdf.

Pu EY. 1995. Studies on stability of liquid/liquid dispersions: Theory and practice [D]. Zrich: Switzerland Union Higher Industry College; Doctor Degree Thesis.

Qiu H, Chen D, Liu Y, Wu X, Ren R, Cheng Q. 2011. Study on anti atheroscloresis effects of daidai flavones dropping pills on hype-lipidemia rats. Chin. J. Mod. Appl. Pharm. 28, 597-601.

Shen JF, Kang R, Chen YQ. 2010. Study on Extraction and anti-oxidation of Camellia oleifera shell polysaccharide. $J$. Chinese J. Grain and Oil 25 (8), 51-54.

Shen TT, Wu SX. 2017. Effects of Tea Seed Oil on Hyperlipidemic Rats Induced by High-fat Diet. Food Sci. Technol. Res. 23 (1), 101-109. https://doi.org/10.3136/fstr.23.101

Shrivenham RH, Xiao CW. 2005. The chemical structure and biological activity of tea saponins research progress (review). J. Anhui Agri. Univ. 01, 369-372.

Tang L, Feng B, Li H, Chen Y, Shi L, Wang Y. 2008. Research progress of Camellia oleifera saponin. J. Central Pharm. 03, 330-333.

Płotka-Wasylka J, Szczepanska N, de la Guardia M, Namiesnik J. 2015. Miniaturized solid-phase extraction techniques. Trends Anal. Chem. 73, 19-38. https://doi.org/10.1016/j. trac.2015.04.026

Wu X, Huang Y, Xie Z. 2005. Health functions and prospective of Camellia oil. J. Food Sci. Technol. 5, 94-96.

WuH, Li C, LiZ, Liu R, Zhang A, Xiao Z, Ma L, Li J, Deng S. 2018. Simultaneous extraction of oil and tea saponin from Camellia oleifera Abel. seeds under subcritical water conditions. Fuel Proc. Tech.174, 88-94. https://doi.org/10.1016/j. fuproc.2018.02.014

Xu DJ, Yan S. 2011. Experimental animals and food safety. Chinese J. Comp. Med. Z 1, 27-29.

Yuan XZ, Meng YT, Zeng GM, Fang YY, Shi JG. 2007. Evaluation of tea-derived bio-surfactant on removing heavy metal ions from dilute wastewater by ion flotation. $J$. Colloids Surf. A: Physicochem. Eng. Asp. 317, 1-3, 256-261.

Zhao LC, He Y, Deng X, Yang GL, Li W, Liang J, Tang QL. 2012. Response Surface Modeling and Optimization of Accelerated Solvent Extraction of Four Lignans from Fructus Schisandrae. Molecules 17, 3618-3629. https://doi. org/10.3390/molecules 17043618 